Supporting Information

\title{
A novel nucleobase that releases reporter tags upon DNA oxidation
}

\author{
Akimitsu Okamoto, Kazuo Tanaka and Isao Saito* \\ Department of Synthetic Chemistry and Biological Chemistry, Faculty of Engineering, Kyoto University, and \\ SORST, Japan Science and Technology Corporation, Kyoto 615-8510, Japan
}

Phone: +81-75-383-2754

FAX: +81-75-753-2759

e-mail: saito@sbchem.kyoto-u.ac.jp 


\section{Materials and Methods}

General. $\quad{ }^{1} \mathrm{H}$ NMR spectra were measured with Varian Mercury $400(400 \mathrm{MHz})$ spectrometer. ${ }^{13} \mathrm{C}$ NMR spectra were measured with JEOL JNM $\alpha-500(500 \mathrm{MHz})$ spectrometer. Coupling constants ( $J$ value) are reported in hertz. The chemical shifts are expressed in ppm downfield from tetramethylsilane, using residual chloroform ( $\delta=7.24$ in ${ }^{1} \mathrm{H}$ NMR, $\delta=77.0$ in ${ }^{13} \mathrm{C}$ NMR) as an internal standard. FAB mass spectra were recorded on JEOL JMS DX-300 spectrometer or JEOL JMS SX-102A spectrometer. Masses of ODNs were determined with a MALDI-TOF mass spectroscopy (acceleration voltage $21 \mathrm{kV}$, negative mode) with 2',3',4'trihydroxyacetophenone (THAP) as matrix, using $\mathrm{T}_{8}\left([\mathrm{M}-\mathrm{H}]^{-}\right.$2370.61) and $\mathrm{T}_{17}\left([\mathrm{M}-\mathrm{H}]^{-}\right.$5108.37) as an internal standard. HPLC was performed on a cosmosil 5C-18AR or CHEMCOBOND 5-ODS-H column (4.6 $\times 150 \mathrm{~mm}$ ) with a Gilson Chromatography Model 305 using a UV detector Model 118 at $254 \mathrm{~nm}$.

\section{8-[2-( $N$-Trifluoroacetylamino)ethyl]amino-2-(,$N$-dimethylaminomethylidenyl)amino-5'-O-(4,4'-}

dimethoxytrityl)-2'-deoxyguanosine (3). A solution of 8-bromo-5'-O-(4,4'-dimethoxytrityl)-2'deoxyguanosine $1(2.0 \mathrm{~g}, 30.8 \mathrm{mmol})$ was stirred in ethylenediamine $(100 \mathrm{~mL})$ at $130{ }^{\circ} \mathrm{C}$ for $7 \mathrm{~h}$. The reaction mixture was concentrated to give a crude product $\mathbf{2}$ as a brown oil. Crude $\mathbf{2}$ was dissolved in triethylamine $(25 \mathrm{~mL})$ and methanol $(50 \mathrm{~mL})$, and then $10 \mathrm{~mL}$ of ethyl trifluoroacetate was added to the mixture at $0{ }^{\circ} \mathrm{C}$. The reaction mixture was stirred at $0{ }^{\circ} \mathrm{C}$ for $2 \mathrm{~h}$, and then concentrated. Subsequently, $N, N$ dimethylformamide $(25 \mathrm{~mL})$ and $N, N$-dimethylformamide dimethylacetal $(25 \mathrm{~mL})$ were added to the residue. The reaction mixture was stirred at ambient temperature for $2 \mathrm{~h}$. After concentration, the residue was purified by column chromatography on silica gel (chloroform : methanol $=30: 1)$ to give compound $\mathbf{3}(1.5 \mathrm{~g}, 63 \%)$ : ${ }^{1} \mathrm{H} \mathrm{NMR}\left(\mathrm{CDCl}_{3}\right) \delta 9.77$ (brs, $\left.1 \mathrm{H}\right), 9.56$ (brs, $\left.1 \mathrm{H}\right), 8.54$ (s, $\left.1 \mathrm{H}\right), 7.34-7.19(\mathrm{~m}, 8 \mathrm{H}), 6.83-6.80(\mathrm{~m}, 5 \mathrm{H})$, $6.48(\mathrm{dt}, 1 \mathrm{H}, J=8.0,4.0 \mathrm{~Hz}), 5.83(\mathrm{brs}, 1 \mathrm{H}), 4.75(\mathrm{~d}, 1 \mathrm{H}, J=5.8 \mathrm{~Hz}), 4.07(\mathrm{~d}, 1 \mathrm{H}, J=2.4 \mathrm{~Hz}), 3.765(\mathrm{~s}, 3$ H), 3.763 (s, $3 \mathrm{H}), 3.76-3.72$ (m, 2 H), 3.38 (d, $1 \mathrm{H}, J=8.4 \mathrm{~Hz}), 3.10$ (s, $3 \mathrm{H}), 3.02$ (s, $3 \mathrm{H}), 3.01-2.95$ (m, 2 H), 2.80-2.60 (m, $3 \mathrm{H}), 2.33(\mathrm{dd}, 1 \mathrm{H}, J=13.3,8.0 \mathrm{~Hz}) ;{ }^{13} \mathrm{C} \mathrm{NMR}\left(\mathrm{CDCl}_{3}\right) \delta 158.92,158.91,158.60,157.56$, $157.19,156.55,151.00,143.55,139.43,134.61,134.57,130.29,129.10,128.42,128.04,127.82,127.73$, $127.55,127.05,120.27,117.41,114.55,113.30,113.27,113.14,87.01,85.74,82.80,77.21,71.87,62.87$, 
55.27, 55.23, 42.65, 41.30, 40.77, 38.73, 35.11; $\mathrm{MS}\left(\mathrm{FAB}, \mathrm{NBA} / \mathrm{CH}_{2} \mathrm{Cl}_{2}\right) \mathrm{m} / z(\%) 779\left[(\mathrm{M}+\mathrm{H})^{+}\right]$; HRMS

(FAB) calcd for $\mathrm{C}_{38} \mathrm{H}_{42} \mathrm{~N}_{8} \mathrm{O}_{7} \mathrm{~F}_{3}\left[(\mathrm{M}+\mathrm{H})^{+}\right]$779.3129, found 779.3128.

3'-(O-Cyanoethyl- $N, N$-diisopropylphosphoramidite)-8-[2-( $N$-trifluoroacetylamino)ethyl]amino-2-( $N, N$ dimethylaminomethylidenyl)amino-5'-O-(4,4'-dimethoxytrityl)-2'-deoxyguanosine (4). To a solution of 3 (70 mg, $89.9 \mu \mathrm{mol})$, 2-cyanoethyl tetraisopropyldiphosphoramidite (31 $\mu \mathrm{L}, 98.9 \mu \mathrm{mol})$ and tetrazole $(7 \mathrm{mg}$, $98.9 \mu \mathrm{mol})$ in acetonitrile $(900 \mu \mathrm{L})$ were added. The reaction mixture was stirred at ambient temperature for $2 \mathrm{~h}$. The mixture of $\mathbf{4}$ was filtered and used with no further purification.

ODN synthesis and characterization. ODNs were synthesized by the conventional phosphoramidite method by using an Applied Biosystems 392 DNA/RNA synthesizer. Synthesized ODNs were purified by reverse phase HPLC on a 5-ODS-H column $(10 \times 150 \mathrm{~mm}$, elution with a solvent mixture of $0.1 \mathrm{M}$ triethylammonium acetate (TEAA), $\mathrm{pH} 7.0$, linear gradient over $30 \mathrm{~min}$ from $5 \%$ to $20 \%$ acetonitrile at a flow rate $3.0 \mathrm{~mL} / \mathrm{min})$. An aliquot of purified ODN solution was fully digested with calf intestine alkaline phosphatase $(50 \mathrm{U} / \mathrm{mL})$, snake venom phosphodiesterase $(0.15 \mathrm{U} / \mathrm{mL})$ and $\mathrm{P} 1$ nuclease $(50 \mathrm{U} / \mathrm{mL})$ at $37{ }^{\circ} \mathrm{C}$ for $3 \mathrm{~h}$. Digested solution was analyzed by HPLC on Cosmosil 5C-18AR or CHEMCOBOND 5-ODS-H column $(4.6 \times 150 \mathrm{~mm})$, elution with a solvent mixture of $0.1 \mathrm{M}$ triethylammonium acetate (TEAA), $\mathrm{pH}$ 7.0, linear gradient over $20 \mathrm{~min}$ from $0 \%$ to $20 \%$ acetonitrile at a flow rate $1.0 \mathrm{~mL} / \mathrm{min}$ ). Concentration of each ODN was determined by comparing a given peak area with those of $0.1 \mathrm{mM}$ standard solution containing dA, $\mathrm{dC}$, dG and dT. Each ODN was characterized by MALDI-TOF MS; 5'-d(TATAAT ${ }^{\text {eda }}$ GTAATAT)-3', m/z 4027.33 (calcd for $[\mathrm{M}-\mathrm{H}]^{-}$4028.72); 5'-d(ATTTATAGTGTGGGTTGTT ${ }^{\text {eda }}{ }^{-}$GTTTATTAT)-3', $\mathrm{m} / \mathrm{z} \quad 8732.87$ (calcd for $[\mathrm{M}-\mathrm{H}]^{-}$8732.69).

Postsynthetic modification of ${ }^{\text {eda }}$ G-containing ODN and its characterization. To a $500 \mu \mathrm{L}$ solution of ${ }^{\text {eda }} \mathrm{G}$-containing ODNs $(60 \mathrm{nmol})$ in $50 \mathrm{mM}$ sodium phosphate buffer $(\mathrm{pH} 7.0)$ was added a solution of a $N$ hydroxysuccinimidyl ester of functional units (benzoic acid and tetramethylrhodamine 5-carboxylic acid) in DMSO $(1 \mathrm{mg} / \mathrm{mL}, 150 \mu \mathrm{L})$, and the mixture was incubated at $4{ }^{\circ} \mathrm{C}$ for $18 \mathrm{~h}$. Modified ODNs were purified by reverse phase HPLC on a 5-ODS-H column $(10 \times 150 \mathrm{~mm}$, elution with a solvent mixture of $0.1 \mathrm{M}$ 
triethylammonium acetate (TEAA), pH 7.0, linear gradient over $20 \mathrm{~min}$ from $0 \%$ to $20 \%$ acetonitrile at a flow rate $3.0 \mathrm{~mL} / \mathrm{min})$. Each ODN was characterized by MALDI-TOF MS; 5'-d(TATAAT[Bz- ${ }^{\text {eda }}$ G]TAATAT)-3' $\left(\right.$ ODN1(Bz- $\left.\left.{ }^{\text {eda }} \mathbf{G}\right)\right), \quad m / z \quad 4132.39$ (calcd for $\left.[\mathrm{M}-\mathrm{H}]^{-} \quad 4132.83\right) ; \quad 5^{\prime}$-d(TATAAT[TAMRA- ${ }^{\text {eda }}$ G]TAATAT)-3' $\left(\right.$ ODN1 $\left(\right.$ TAMRA $\left.\left.{ }^{\text {eda }} \mathbf{G}\right)\right), \quad m / z \quad 4442.34 \quad\left(\right.$ calcd $\quad$ for $\left.\quad[M-H]^{-} \quad 4442.17\right) ; \quad 5^{\prime}-$ d(ATTTATAGTGTGGGTTGTT[TAMRA- ${ }^{-\mathrm{eda}}$ G]TTTATTAT)-3' (ODN2), $\mathrm{m} / \mathrm{z} 9146.57$ (calcd for $[\mathrm{M}-\mathrm{H}]^{-}$ 9146.12).

Oxidation of $\mathrm{Bz}^{-\mathrm{eda}} \mathrm{G}$-containing $\mathrm{ODN}$ by photoirradiation in the presence of riboflavin. A solution of single-stranded ODN 5'-d(TATAATXTAATAT)-3' $\left(\mathbf{X}=\right.$ Bz- $\left.^{\text {eda }} \mathrm{G}\right)(10 \mu \mathrm{M})$ in sodium cacodylate buffer (pH 7.0) was irradiated at $366 \mathrm{~nm}$ at $0{ }^{\circ} \mathrm{C}$ for $30 \mathrm{~min}$ in the presence of riboflavin $(50 \mu \mathrm{M})$. After irradiation, the reaction mixture was analyzed by HPLC on Cosmosil 5C-18AR or CHEMCOBOND 5-ODS-H column (4.6 × $150 \mathrm{~mm}$ ), elution with a solvent mixture of $0.1 \mathrm{M}$ triethylammonium acetate (TEAA), $\mathrm{pH}$ 7.0, linear gradient over $30 \mathrm{~min}$ from $0 \%$ to $30 \%$ acetonitrile at a flow rate $1.0 \mathrm{~mL} / \mathrm{min})$. HPLC profile is shown in Figure S1(b). The modified ODN was completely consumed within $30 \mathrm{~min}$ by photoirradiation. The reaction products were analyzed using MALDI-TOF MS and LC-ESI/MS/MS. ODN fragments 5, [M-H] $]^{-}$, calcd. 1968.32, found 1967.68 by MALDI-TOF (Figure S2); 5'-phosphate end 6, [M-H]', calcd. 1870.22, found 1870.11 by MALDI-TOF (Figure S2); a benzamide 7, $\mathrm{M}^{+}, 207$ and its fragments 148, 105, 77 and 59 by LC-ESI/MS/MS (Figure S3).

Oxidation of Bz- ${ }^{\text {eda }} \mathbf{G}$-containing ODN by $\operatorname{Ir}(\mathbf{I V})$. A solution of single-stranded ODN 5'd(TATAATXTAATAT)-3' $\left(\mathbf{X}=\right.$ Bz- $\left.^{-{ }^{\text {da }}} \mathrm{G}\right)(10 \mu \mathrm{M})$ in sodium cacodylate buffer $(\mathrm{pH}$ 7.0) was incubated at room temperature for $15 \mathrm{~min}$ in the presence of sodium hexachloroiridate(IV) $(20 \mu \mathrm{M})$. After reaction, the reaction mixture was analyzed by HPLC on Cosmosil 5C-18AR or CHEMCOBOND 5-ODS-H column $(4.6 \times 150$ $\mathrm{mm}$ ), elution with a solvent mixture of $0.1 \mathrm{M}$ triethylammonium acetate (TEAA), $\mathrm{pH}$ 7.0, linear gradient over $30 \mathrm{~min}$ from $0 \%$ to $30 \%$ acetonitrile at a flow rate $1.0 \mathrm{~mL} / \mathrm{min}$ ). HPLC profile is shown in Figure S1(c). $57 \%$ of modified ODN was consumed in 15 min incubation. In a similar manner, a solution of single-stranded ODN 5'-d(TATAATXTAATAT)-3' (X = TAMRA- $\left.{ }^{\text {eda }} \mathrm{G}\right)(10 \mu \mathrm{M})$ in sodium cacodylate buffer (pH 7.0) was incubated at room temperature for $15 \mathrm{~min}$ in the presence of sodium hexachloroiridate(IV) $(50 \mu \mathrm{M}) .89 \%$ of 
modified ODN was consumed in 15 min incubation.

Hole transport experiment and fluorescence analysis. $\quad$ The ODN 5'd(ATTTATAGTGTGGGTTGTT[TAMRA- ${ }^{\text {eda }}$ G]TTTATTAT)-3' was hybridized with the complementary strand containing cyanobenzophenone-substituted uridine (U*) in $10 \mathrm{mM}$ sodium cacodylate buffer (pH 7.0). Hybridization was achieved by heating the sample at $90^{\circ} \mathrm{C}$ for $5 \mathrm{~min}$ and slowly cooling to room temperature. Photoirradiation was then carried out for a solution containing duplex (1 $\mu \mathrm{M}$ strand concentration) in $10 \mathrm{mM}$ sodium cacodylate buffer at $\mathrm{pH}$ 7.0. The mixture was irradiated with a transilluminator ( $312 \mathrm{~nm})$ at a distance of $3 \mathrm{~cm}$ at $0{ }^{\circ} \mathrm{C}$ for $1 \mathrm{~h}$. After irradiation, ODN was removed from samples by centrifugation $(15,000 \mathrm{rpm})$ with Microcon (YM-3, 3,000 MWCO), centrifugal filter devices, at $25{ }^{\circ} \mathrm{C}$ for $1 \mathrm{~h}$. The fluorescence of the filtrate was measured with an excitation wavelength of $550 \mathrm{~nm}$ using a SHIMADZU RF-5300PC spectrofluorophotometer.

Preparation of ${ }^{32} \mathbf{P}-5$ '-end-labeled oligomers. The ODN 5'-d(ATTTATAGTGTGGGTTGTTITAMRA-

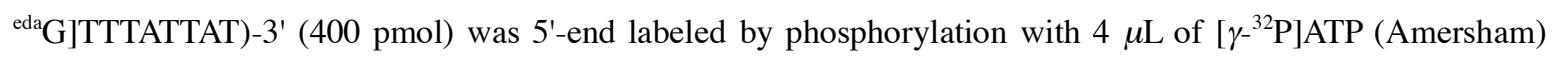
and T4 polynucleotide kinase using a standard procedure. The 5'-end labeled ODN was recovered by ethanol precipitation and further purified by $15 \%$ denaturing polyacrylamide gel electrophoresis (PAGE) and isolated by the crush and soak method.

Hole transport experiment and PAGE analysis. The ODN $55^{1}{ }^{32} \mathrm{P}-$ d(ATTTATAGTGTGGGTTGTT[TAMRA- ${ }^{\text {eda }}$ G]TTTATTAT)-3' $\left(2.0 \times 10^{5} \mathrm{cpm}\right)$ was hybridized with the complementary strand containing cyanobenzophenone-substituted uridine ( $\left.\mathbf{U}^{*}\right)$ in $10 \mathrm{mM}$ sodium cacodylate buffer ( $\mathrm{pH} 7.0)$. Hybridization was achieved by heating the sample at $90{ }^{\circ} \mathrm{C}$ for 5 min and slowly cooling to room temperature. Photoirradiation was then carried out for a solution containing duplex (1 $\mu \mathrm{M}$ strand concentration) in $10 \mathrm{mM}$ sodium cacodylate buffer at $\mathrm{pH}$ 7.0. The mixture was irradiated with a transilluminator $(312 \mathrm{~nm})$ at a distance of $3 \mathrm{~cm}$ at $0{ }^{\circ} \mathrm{C}$ for $1 \mathrm{~h}$. After irradiation, all reaction mixtures were precipitated with the addition of $10 \mu \mathrm{L}$ of $3 \mathrm{M}$ sodium acetate, $20 \mu \mathrm{L}$ of herring sperm DNA ( $50 \mu \mathrm{M}$ base pair concentration) and $800 \mu \mathrm{L}$ of ethanol. The precipitated ODN was washed with $100 \mu \mathrm{L}$ of $80 \%$ cold ethanol 
and dried in vacuo. The precipitated ODN was resolved in $50 \mu \mathrm{L}$ of $10 \%$ piperidine $(v / v)$, heated at $90{ }^{\circ} \mathrm{C}$ for 20 min., evaporated by vacuum rotary evaporation to dryness and resuspended in 5-20 $\mu \mathrm{L}$ of $80 \%$ formamide loading buffer (a solution of $80 \% v / v$ formamide, $1 \mathrm{mM}$ EDTA, $0.1 \%$ xylenecyanol and $0.1 \%$ bromophenol blue). All reactions, along with Maxam-Gilbert G+A sequencing reactions, were conducted with heating at $90{ }^{\circ} \mathrm{C}$ for $1 \mathrm{~min}$, and quickly chilled on ice. The samples $(1 \mu \mathrm{L}, 3-10 \mathrm{kcpm})$ were loaded onto $15 \%$ denaturing 19:1 acrylamide-bisacrylamide gel containing $7 \mathrm{M}$ urea and electrophoresed at $1900 \mathrm{~V}$ for approximately $1.5 \mathrm{~h}$ and transferred to a cassette and stored at $-80^{\circ} \mathrm{C}$ with Fuji X-ray film. 


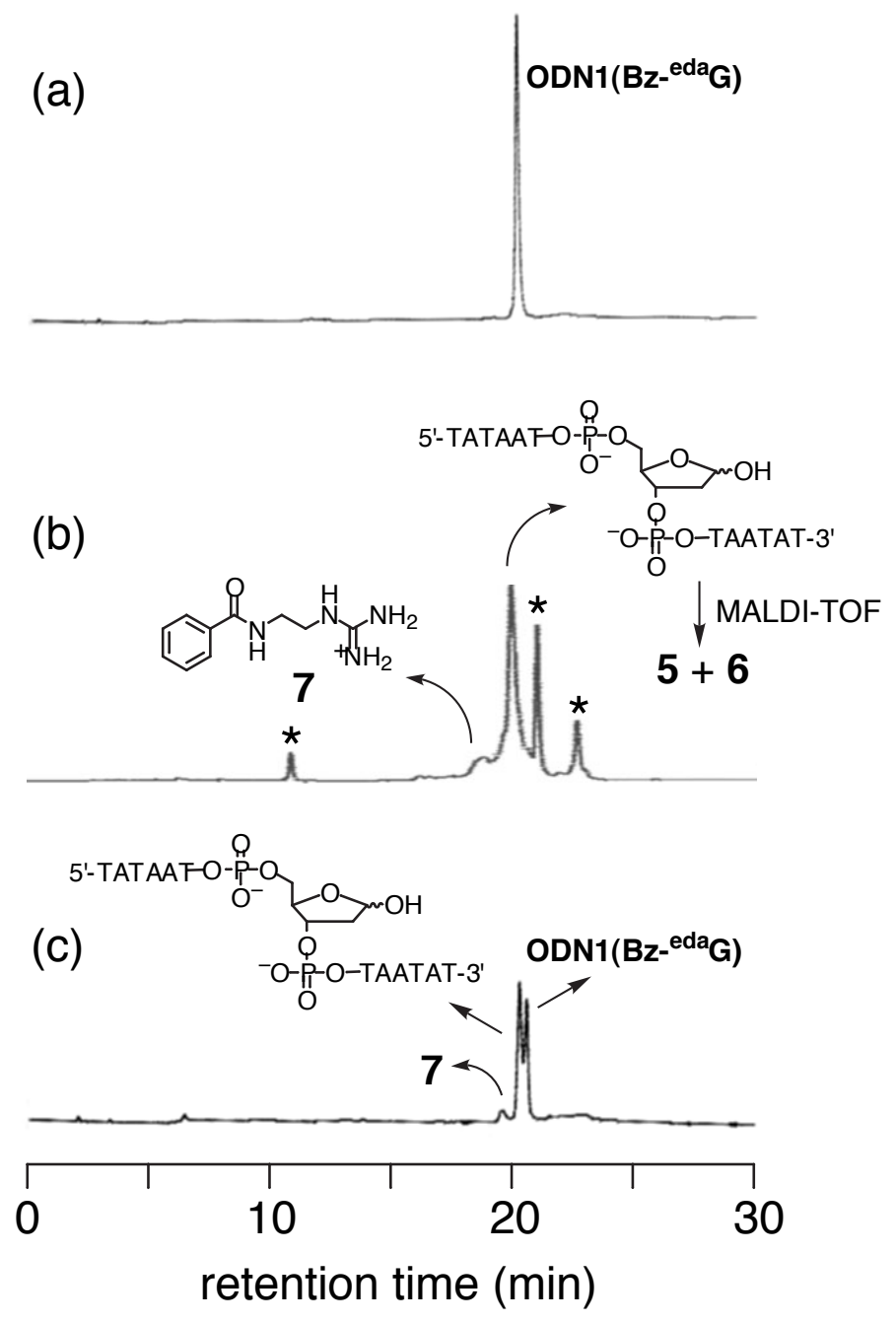

Figure S1. Typical HPLC profiles for the oxidation of $\mathrm{Bz}^{-\mathrm{eda}} \mathrm{G}-\mathrm{containing} \mathrm{ODN}$. The reaction mixture was analyzed by HPLC on Cosmosil 5C-18AR or CHEMCOBOND 5-ODS-H column $(4.6 \times 150 \mathrm{~mm})$, elution with a solvent mixture of $0.1 \mathrm{M}$ triethylammonium acetate (TEAA), $\mathrm{pH}$ 7.0, linear gradient over 30 min from $0 \%$ to $30 \%$ acetonitrile at a flow rate $1.0 \mathrm{~mL} / \mathrm{min}$ ). (a) $\mathbf{O D N 1}\left(\mathbf{B z}-{ }^{\text {eda }} \mathbf{G}\right)$. (b) Photolysis of ODN1(Bz- $\left.{ }^{\text {eda }} \mathbf{G}\right)$ by photoirradiation in the presence of riboflavin. A solution of the modified ODN $(10 \mu \mathrm{M})$ in sodium cacodylate buffer (pH 7.0) was irradiated at $366 \mathrm{~nm}$ at $0{ }^{\circ} \mathrm{C}$ for $30 \mathrm{~min}$ in the presence of riboflavin $(50 \mu \mathrm{M})$. “*” denotes

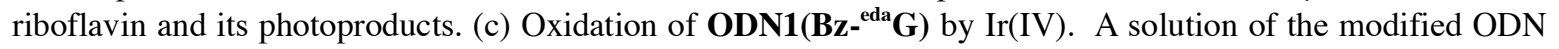
$(10 \mu \mathrm{M})$ in sodium cacodylate buffer $(\mathrm{pH} 7.0)$ was incubated at room temperature for $15 \mathrm{~min}$ in the presence of sodium hexachloroiridate(IV) $(20 \mu \mathrm{M})$. 


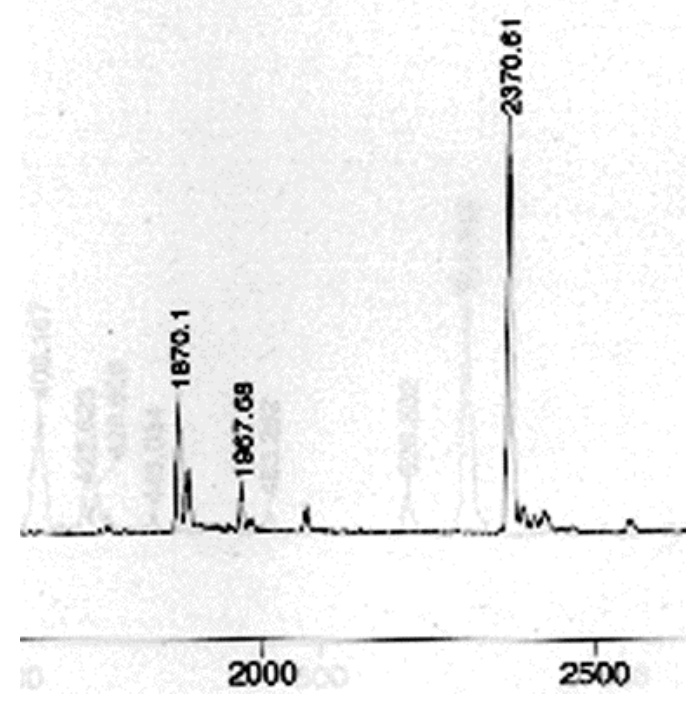

Figure S2. Mass spectroscopic analysis of UV-irradiated ODN1(Bz- $\left.{ }^{\text {eda }} \mathbf{G}\right)$. The mass of photoirradiated ODN was determined by MALDI-TOF mass spectroscopy (acceleration voltage $21 \mathrm{kV}$, negative mode) with $2^{\prime}, 3^{\prime}, 4^{\prime}-$ trihydroxyacetophenone (THAP) as matrix, using THAP $\left([\mathrm{M}-\mathrm{H}]^{-} 167.04\right)$ and $\mathrm{T}_{8}\left([\mathrm{M}-\mathrm{H}]^{-} 2370.61\right)$ as an internal standard. ODN fragments cleaved via an abasic nucleotide, $5\left([\mathrm{M}-\mathrm{H}]^{-}\right.$, calcd. 1968.32, found 1967.68) and $\mathbf{6}\left([\mathrm{M}-\mathrm{H}]^{-}\right.$, calcd. 1870.22, found 1870.11) were found. 


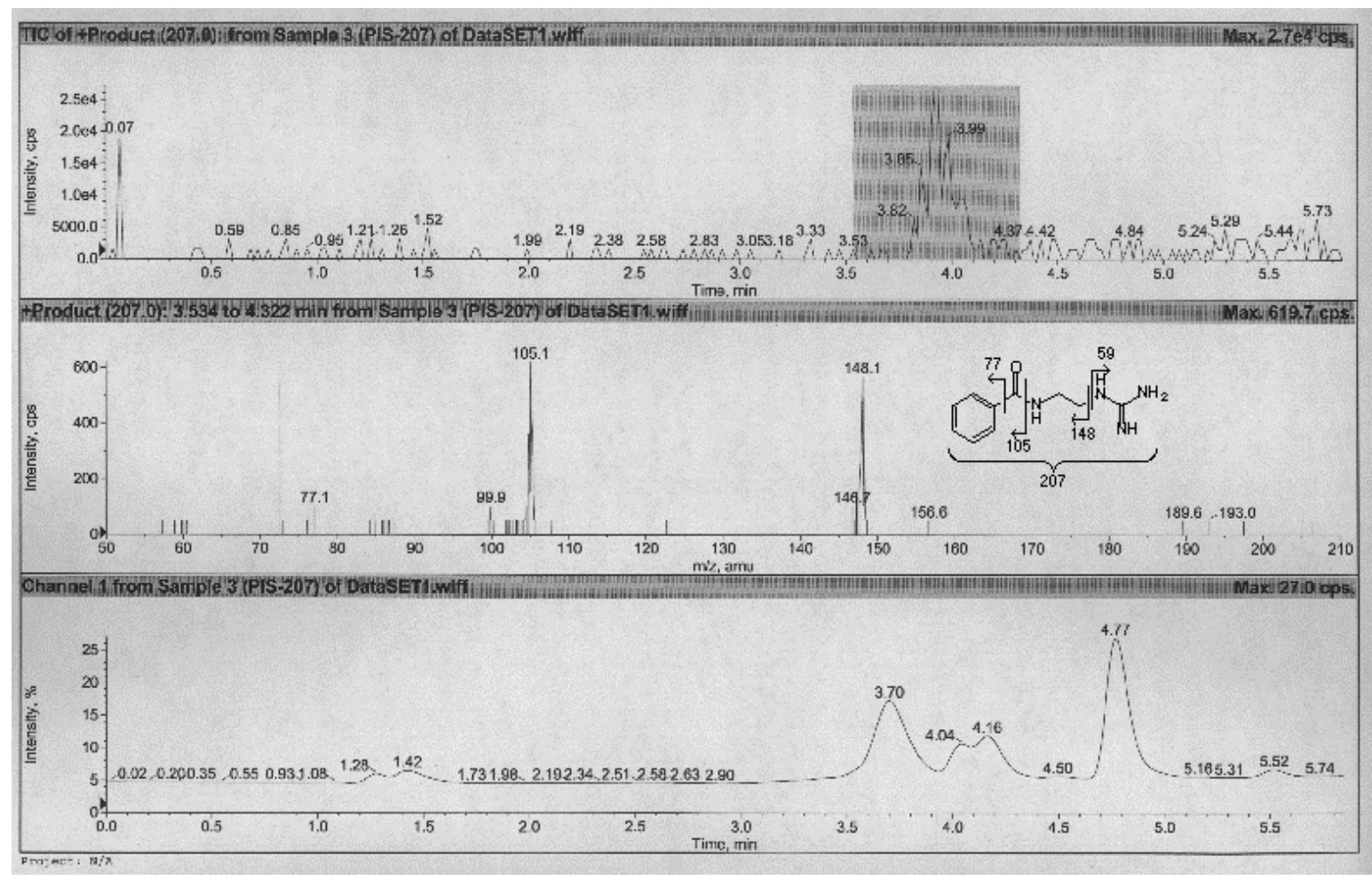

Figure S3. Mass spectroscopic analysis of UV-irradiated ODN1(Bz- $\left.{ }^{\text {eda }} \mathbf{G}\right)$. The mass of photoirradiated ODN was determined by LC-ESI/MS/MS spectroscopy. Top, eluate containing MS 207; middle, fragments of MS 207; bottom, LC profile on a Intakt C-18 column $(2.0 \times 50 \mathrm{~mm})$ detected at $254 \mathrm{~nm}$; elution with a solvent mixture of $0.1 \mathrm{M}$ triethylammonium acetate ( $\mathrm{pH} \mathrm{7.0),0-90 \%} \mathrm{acetonitrile} \mathrm{for} 5 \mathrm{~min}$ and $90 \%$ acetonitrile for 2 $\mathrm{min}$ at a flow rate $0.2 \mathrm{~mL} / \mathrm{min}$. The retention time for the product possessing MS 207 is $3.70 \mathrm{~min}$. The peak of retention time of $4.77 \mathrm{~min}$ is riboflavin. 


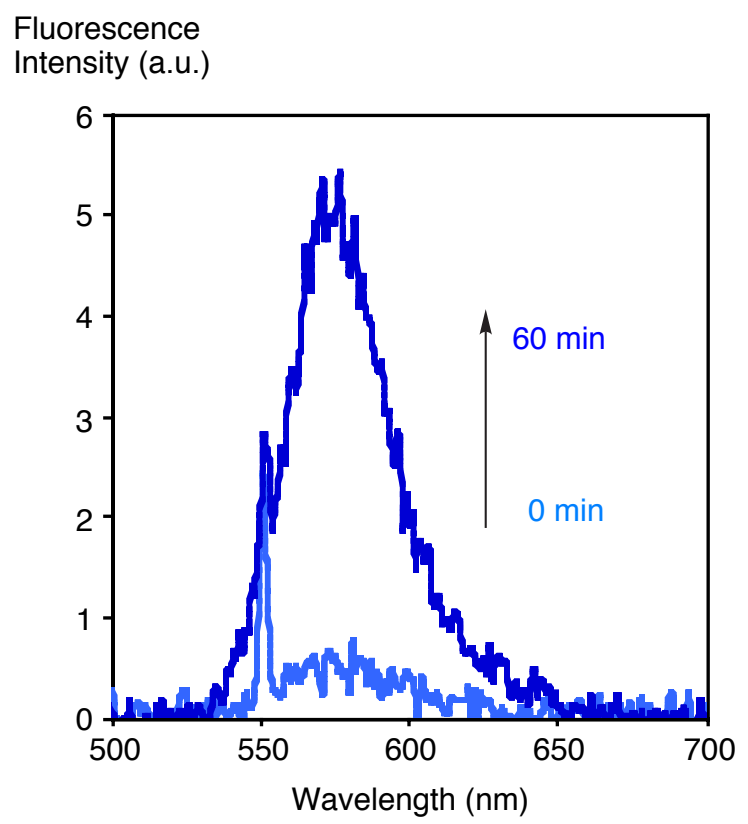

Figure S4. Fluorescence intensity of the reaction samples of ODN2/ODN2'(U*) after photoirradiation $(\lambda=$ $312 \mathrm{~nm}$ ) and removal of ODN. The duplexes in $10 \mathrm{mM}$ sodium cacodylate $(\mathrm{pH} 7.0)$ were irradiated at $0{ }^{\circ} \mathrm{C}$ followed by centrifugation (15,000 rpm) with Microcon (YM-3, 3,000 MWCO), centrifugal filter devices, at $25{ }^{\circ} \mathrm{C}$ for $1 \mathrm{~h}$. The fluorescence of the filtrate was measured with an excitation wavelength of $550 \mathrm{~nm}$ using a SHIMADZU RF-5300PC spectrofluorophotometer. 


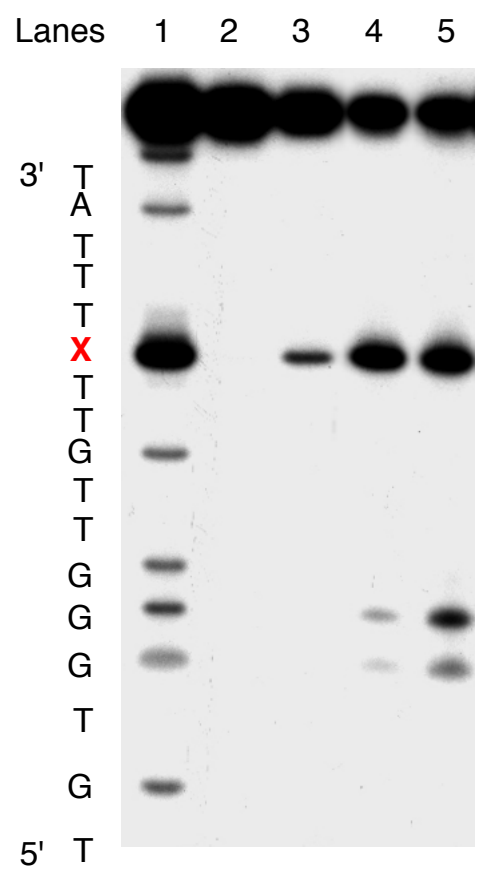

Figure S5. PAGE analysis of the photolysate. The ${ }^{32} \mathrm{P}$-labeled ODN2 was hybridized with ODN2'(U*) in 10 $\mathrm{mM}$ sodium cacodylate buffer ( $\mathrm{pH}$ 7.0). Photoirradiation was then carried out on a solution containing duplex (1 $\mu \mathrm{M}$ strand concentration) in $10 \mathrm{mM}$ sodium cacodylate buffer at $\mathrm{pH}$ 7.0. The mixture was irradiated with a transilluminator $(312 \mathrm{~nm})$ at a distance of $3 \mathrm{~cm}$ at $0{ }^{\circ} \mathrm{C}$. The photoirradiated ODN was heated in $50 \mu \mathrm{L}$ of $10 \%$ piperidine $(v / v)$ at $90{ }^{\circ} \mathrm{C}$ for $20 \mathrm{~min}$. $\mathbf{X}$ denotes TAMRA- ${ }^{\text {eda }} \mathrm{G}$. Lane 1 , Maxam-Gilbert G+A sequencing reactions; lane 2, intact ODN2; lane 3, 0 min photoirradiation and hot piperidine treatment; lane 4, $30 \mathrm{~min}$ photoirradiation and hot piperidine treatment; lane 5,60 min photoirradiation and hot piperidine treatment. 